\title{
Kajian Rekognisi Hak Masyarakat Adat Perspektif Propetik
}

\author{
Supriyadi \\ ${ }^{1}$ Fakultas Hukum, Institut Ilmu Sosial dan Ilmu Budaya Samawa Rea, \\ Emailsupriyadi@gmail.com
}

\begin{abstract}
Abstrak. Penelitian ini dilatarbelakangi tidak adanya etik dalam pengakuan masyarakat adat di Indonesia. Penelitian ini menggunakan metode normative dengan pendekatan konseptual dan pendekatan peraturan perundang-undangan dengan tujuan penelitian ini adalah agar menjadi referensi pemegang kebijakan dalam membuat regulasi agar memperhatikan asas-asas hokum.

Artikel ini berbicara tentang rekognisi hak masyarakat adat perspektif etik profetik dengan latar belakang bahwa konstitusi UUD NRI 1945 tidak memuat nilai etik dalam rekognisi hak masyarakat adat.Tujuan artikel ini untuk menjadi bahan dalam pengambilan kebijakan amandemen konstitusi. Metode yang digunakan dalam penelitian ini adalah penelitian normatif dengan pendekatan filsafat. Hasil penelitian ini adalah integrasi rekognisi efektif, rekognisi etis dan rekognisi affirmatif menjadi nilai etik propetik rekognisi hak masyarkat adat.
\end{abstract}

Kata Kunci: Rekognisi, Pesprspektig Propetik

\section{LATAR BELAKANG}

Tulisan ini mengupas terkait Posisining rekognisi hak masyarakat adatperspektif etik profetik. Rekognisi idealnya dilakukan dengan pendekatan secara utuh dan affirmatife. Rekognisi dengan pendekatan secara utuh menjamin hak asasi bagi yang direkognisi. Rekognisi affirmative menjamin percepatan rekognisi bagi kelompok atau komunitas yang dulunya pernah ada, lalu direkognisi kembali. Intergrasi antara rekognisi utuh dan affirmative ini disebut sebagai rekognisi etis. Rekognisi etis ini roh dari rekognisi perspektif etik propetik.

Rekognisi hak masyarkat adat diatur dalam UUD NRI 1945 dengan berbagai pendekatan yang dimuat pada masing-masing pasal. Pasal 18B ayat (2) rekognisi dengan pendekatan Tata Pemerintahan, pasal 32 Ayat (1) dan (2) rekoginisi menggunakan pendekatan kebudayaan, pasal 28I rekognisi menggunakan pendekatan hak asasi manusia. Rekognisi dalam konstitusi dengan Pendekatan-Pendekatan tersebut berdampak persoalan hukum pada tataran peraturan dibawahnya bahkan masih menyimpan konflik di wilayah masyarakat adat baik konflik vertikal maupun konflik horizontal. Konflik tersebut terus terjadi karena rekognisi masyarakat adat tidak dilakukan secara penuh dan efektif sehingga tidak telihat moral etik dalam muatan rekognisi hak masyarakat adat dalam konstitusi.
Berdasarkan teori Honneth, politik rekognisi memiliki tiga ranah yang berbeda namun saling berkaitan: cinta, hukum/hak, dan solidaritas yang masing-masing memiliki konturnya sendiri beserta jenis ancaman yang berbeda pula. Di samping itu juga, dalam Perjanjian Westphalia 1648 selain mengakhiri Perang 30 tahun di daratan Eropa yang dipicu oleh Reformasi oleh Marthin Luther di Jerman, juga mengakhiri hegemoni politik Gereja Katholik Roma atas Negara-negara di Eropa dan berbagai belahan dunia lainnya.Perjanjian Westphalia mengedepankan dua hal penting yang berkembang di Eropa waktu itu yaitu pertama,pengakuan Negara bangsa sebagai entitas paling berdaulat di hadapan warga negaranya; dan kedua Negara lain tidak berhak mencederai kedaulatan tersebut dalam sebuah sistem internasional.

Rekognisi dalam pandangan etik propetik yang berdasar pada fiqih aqalliyat yang secara etimologis dimaknai minoritas atau kelompok. Didefinisikan sebagai kelompok masyarakat dalam suatu pemerintahan yang dalam hal etnis, bahasa, ras, atau agama berbeda dengan kelompok mayoritas yang berkembang.Secara terminolgis Fikih Minoritas berarti satu bentuk fiqh yang memeilihara keterkaitan hukum syar'i dengan dimensidimensi suatu komunitas, dan dengan tempat di mana mereka tinggal.Fiqh ini merupakan fiqh 
komunitas terbatas yang memiliki kondisi khusus, yang memungkinkan sesuatu yang tidak sesuai bagi orang lain menjadi sesuai bagi mereka.

Pendekatan yang dilupakan dalam rekognisi hak masyarakat adat dalam konstitusi adalah pendekatan Sumber daya alam dan pendekatan Hukum adat. Upaya rekognisi dengan pendekatan Sumber daya alam dengan melakukan yudicial review undang-undang nomor 41 Tahun 1999 Tentang kehutanan yang melahirkan putusan Mahkamah Konstitusi (MK) No 35/PUUX/ 2012 yang menyatakan teritorialisasi wilayah hutan adat sebagai hutan negara yang diatur dalam UU Nomor 41 Tahun 1999 tentang Kehutanan bertentangan dengan UUD NRI 1945. Pendekatan Hukum adat belum diakomodir sehingga peradilan adat menjadi alternatif penyelesaian sengketa.

Muhammad Dahlan mengkaji rekognisi hak masyarakat hukum adat dalam konstitusi yang pernah berlaku di indonesia dengan melihat efektif atau tidak rekognisi tergantung pada lima klasifikasi rekognisi yaitu rekognisi konstitusional atas perbedaan kultural, rekognisi konstitusional atas hak menentukan nasib sendiri secara budaya, rekognisi konstitusional atas hukum adat, rekognisi konstitusional atas hak berpolitik, serta rekognisi konstitusional atas hak mengklaim dan berjuang untuk hak komunal atas tanah, teritori dan sumber daya alam dengan keseimpulannnya bahwa tidak satupun dari Konstitusi yang pernah berlaku di Indonesia secara penuh memberikan pengakuan dan perlindungan terhadap hak MHA dan implementasi dari Konstitusi tersebut yang memenuhi klasifikasi rekognisi hak MHA secara penuh.

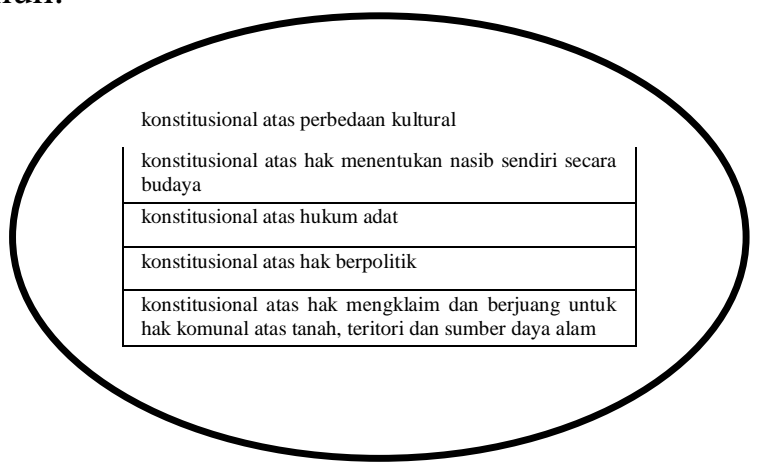

Gambar 1: Rekognisi Efektif (Data diolah dari Penelitian Dahlan)
Tulisan ini akan fokus pada analisa rekognisi hak masyarakat adat perspektif etik profetik dengan melihat pendekatan rekognisi hak masyarakat adat yang diatur dalam UUD NRI 1945 dengan Metode penelitian normatif yang dalam hal ini studi kepustakaan dengan jenis penelitian normatif serta menggunakan metode pendekatan konseptual, pendekatan perundang-undangan, pendekatan filsafat. Sumber bahan hokum adalah UUD NRI 1945, Undang-Undang, Jurnal, Buku-Buku.Metode analisis bahan hokum dengan metode deduktif.

\section{HASIL DAN PEMBAHASAN}

\section{a. Rekognisi Hak Masyarakat Adat Dalam Konstitusi}

Dalam konstitusi mengatur rekognisi hak masyarakat adat dengan pendekatan :

1. Pendekatan tata pemerintahan (pasal 18B ayat (2))

Secara Konstitusioal pengaturan masyarkat adat sebelum amandemen sering berdasar pada Penjelasan UUD 1945 Pasal 18 angka II yang berbunyi:

"Dalam territoir Negara Indonesia terdapat lebih kurang 250 zelfbesturende landchappen dan volksgetneenschappen, seperti desa di Jawa dan Bali, negeri di Minangkabau, dusun dan marga di Palembang dan sebagainya.Daerahdaerah itu mempunyai susunan asli, dan oleh karenanya dapat dianggap sebagai daerah yang bersifat istimewa.Negara Republik Indonesia menghormati kedudukan daerahdaerah istimewa tersebut dan segala peraturan negara yang mengenai daerah-daerah itu akan mengingati hak-hak asal-usul daerah tersebut."

Dalam UUD NRI 1945 Pasal 18B ayat (2) merujuk kepada kesatuankesatuan masyarakat adat yang secara kelembagaan merujuk pada desa, nagari, dusun, marga atau bentuk lainnya. Oleh karena itu, pembicaraan mengenai masyarakat adat dalam tulisan ini adalah membicarakan masyarakat adat yang dimaksud dalam Pasal 18B ayat (2) UUD 1945 Pasal 18B ayat (2) UUD 1945 sebagai salah satu landasan 
konstitusional masyarakat adat menyatakan pengakuan secara deklaratif bahwa negara mengakui dan menghormati keberadaan dan hak-hak masyarakat adat. Pasal 18B ayat (2) berbunyi :

"Negara mengakui dan menghormati kesatuan-kesatuan masyarakat hukum adat beserta hak-hak tradisionalnya sepanjang masih hidup dan sesuai dengan perkembangan masyarakat dan prinsip Negara Kesatuan Republik Indonesia, yang diatur dalam undang-undang."

Pengakuan tersebut memberikan batasan-batasan atau persyaratan agar suatu komunitas dapat diakui keberadaan sebagai masyarakat adat. Ada empat persyaratan keberadaan masyarakat adat menurut Pasal 18B ayat (2) UUD 1945 antara lain:

a. Sepanjang masih hidup

b. Sesuai dengan perkembangan masyarakat

c. Prinsip Negara Kesatuan Republik Indonesia

d. Diatur dalam undang-undang

2. Pendekatan HAM (pasal 28i (1) dan (2))

Pengaturan terkait hak-hak masyarakat adat diatur dalam Pasal 28I ayat (3) berbunyi:

"Identitas budaya dan hak masyarakat tradisional dihormati selaras dengan perkembangan zaman dan peradaban."

Secara substansial, pola materi muatan dari Pasal 28I ayat (3) ini hampir sama dengan materi muatan Pasal 6 ayat (2) UU No. 39 Tahun 1999 tentang Hak Asasi Manusia (UU HAM) yang berbunyi: "Identitas budaya masyarakat hukum adat, termasuk hak atas tanah ulayatdilindungi, selaras dengan perkembangan zaman. "UU HAM lahir satu tahun sebelum dilakukannya amandemen terhadap Pasal 28I ayat (3) UUD 1945.Kuat dugaan, Pasal 28I ayat (3) UUD 1945 dan juga beberapa ketentuan terkait hak asasi manusia lainnya di dalam konstitusi mengadopsi materi muatan yang ada di dalam UU HAM.

Namun ada sedikit perbedaan antara Pasal 28I ayat (3) UUD 1945 dengan Pasal 6 ayat (2) UU HAM. Pasal 6 ayat (2) UU HAM mengatur lebih tegas dengan menunjuk subjek masyarakat hukum adat dan hak atas tanah ulayat.Sedangkan Pasal 28I ayat (3) membuat rumusan yang lebih abstrak dengan menyebut hak masyarakat tradisional.

Hak masyarakat tradisional itu sendiri merupakan istilah baru yang sampai saat ini belum memiliki definisi dan batasan yang jelas.Pasal 28I ayat (3) UUD 1945 juga mempersyaratkan keberadaan dan hak-hak masyarakat adat sepanjang sesuai dengan perkembangan zaman.Pendekatan konstitusional terhadap Pasal 28I ayat (3) UUD 1945 ini adalah pendekatan HAM. Hal ini nampak jelas dalam sistematika UUD 1945 yang meletakkan Pasal 28I ayat (3) UUD 1945 di dalam Bab XA tentang Hak Asasi Manusia bersamaan dengan hak-hak asasi manusia lainnya. Oleh karena itu, instansi pemerintah yang paling bertanggungjawab dalam landasan konstitusional ini adalah Kementerian Hukum dan HAM serta Komisi Nasional Hak Asasi Manusia.

3. Pendekatan Kebudayaan (pasal 31 (2))

Dalam konstitusi yang berkaitan dengan keberadaan dan hak-hak masyarakat adat adalah Pasal 32 ayat (1) dan ayat (2) UUD 1945 yang berbunyi:

Pasal 32 ayat (2)

"Negara memajukan kebudayaan nasional Indonesia di tengah peradaban dunia dengan menjamin kebebasan masyarakat dalam memelihara dan mengembangkan nilai-nilai budayanya."

Pasal 32 ayat (2)

"Negara menghormati dan memelihara bahasa daerah sebagai kekayaan budaya nasional."

Kedua ketentuan ini tidak terkait langsung dengan hak masyarakat adat 
atas sumber daya alam. Namun dalam kehidupan keseharian masyarakat adat, pola-pola pengelolaan sumber daya alam tradisional sudah menjadi budaya tersendiri yang berbeda dengan pola-pola yang dikembangkan oleh masyarakat industri.Pola-pola pengelolaan sumber daya alam inilah yang kemudian menjadi salah satu kearifan lokal atau kearifan tradisional masyarakat dalam pengelolaan sumber daya alam dan lingkungan hidup.

Ketentuan ini menjadi landasan konstitusional dalam melihat masyarakat dari dimensi kebudayaan. Hak yang diatur dalam ketentuan ini yaitu hak untuk mengembangkan nilai-nilai budaya dan bahasa daerah. Tidak dapat dipungkiri bahwa pendekatan kebudayaan dalam melihat adat istiadat dari masyarakat adat menjadi pendekatan yang paling aman bagi pemerintah karena resiko pendekatan ini tidak lebih besar dibandingkan dengan pendekatan lainnya.

Rekognisi konstitusional atas perbedaan kultural (constitutional recognitionof cultural diversity). Klasifikasi ini menuntut adanya pengakuan terhadap keragaman budaya oleh negara sebagai elemen struktural dari sistem sosial politik seperti Bolivia yang mendefinisikan dirinya sebagai negara plurinasional. Tiap MHA memiliki otonominya masing -masing dan tidak ada satupun dalih yang membenarkan tindakan hukum dari negara untuk mengenyampingkan otonomi tersebut kecuali melalui proses yang demokratis dan terbuka.

Dalam konstitusi tidak mengatur rekognisi hak masyarakat adat dengan pendekatan :

1. Pendekatan Sumber daya Alam

Rekognisi konstitusional atas hak mengklaim dan berjuang untuk hak komunal atas tanah, teritori dan sumber daya alam (constitutional recognitionof right to claim and fight for collective rights of lands, teritories, and natural resources). 25
Rekognisi ini dipandang empat sarjana tersebut sebagai elemen paling penting di era kontemporer karena segala macam bentuk pelanggaran hak asasi manusia terhadap klasifikasi kelima akan meluas pada aspek rekognisi lainnya.

2. Pendekatan Hukum adat

Rekognisi konstitusional atas hukum adat (constitutional recognition of customary law). Klasifikasi ini pertama-tama menuntutadanya pengakuan hukum adat sebagai hukum yang memiliki kekuatanotoritarif bagi masyarakat dalam sudut pandang negara dan keduarekognisi ini menurut adanya perombakan hukum besar-besaranke arah pluralisme hukum (dalam tradisi hukum Amerika Latin disebut derechos consetudinarios). Rekognisi ini akan membebaskan MHAterhadap pilihan hukum; membebaskan mereka untuk membangunsistem peradilan prakolonial maupun sistem sanksi yang pernah ada(tetapi dengan syarat bahwa sanksi yang diberikan tidak merengguthak hidup orang lain seperti tradisi persembahan) dan mekanismeresolusi konflik secara adat.

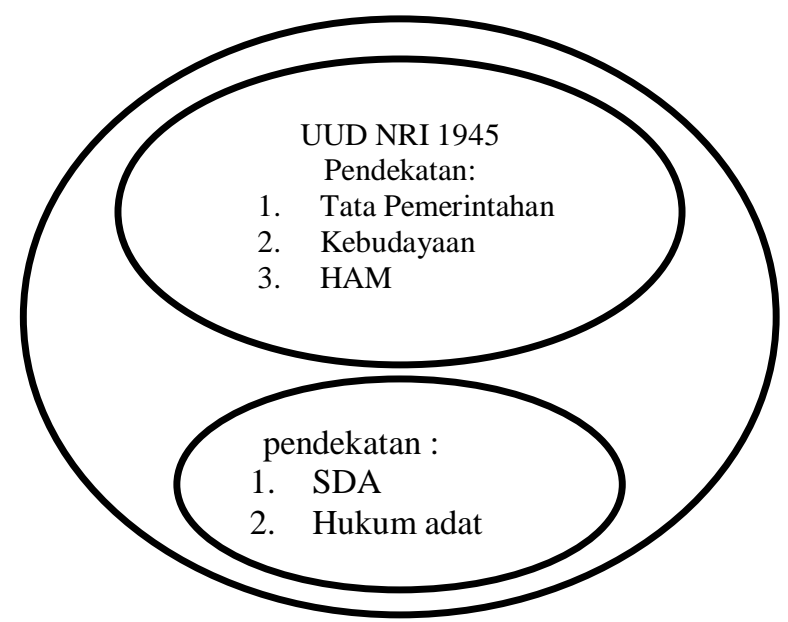

Gambar 2 : Rekognisi Etis

\section{b. Rekognisi hak masyarakat Perspektif Etik Profetik}

Kata profetik berasal dari bahasa inggris "profephet" yang berarti nabi, jadi makna profetik adalah mempunyai sifat atau 
ciri seperti nabi, atau bersifat prediktif.Salah satu sifat nabi adalah mengakuai eksistensi kaum minoritas.Untuk memahami etik rekognisi hak masyarakat adat pespektif etik profetik, perlu pemahaman terkait ilmu dan agama. Menurut kunto, salah satu pola menintegrasikan antara ilmu dan agama yaitu dengan pengilmuan islam (profetik/ demistifikasi) gerakan demistifikasi dimaksudkan sebgai gerakan intelektual untuk menghubungkan kembali teks dengan konteks sehingga terjadi korespodensi.

Dalam konteks ini, etik rekognisi hak masyarakat adat pespektif profetik diteropong dengan Fiqh al-aqalliyyât.Fiqh al-aqalliyyât mendasarkan argumentasiargumentasinya pada logika dan metodologi hukum Islam yang dirumuskan para ulama.Landasan paling dasar yang biasa digunakan, doktrin kemaslahatan dan urf (tradisi).Dengan demikian, sumber-sumber penetapan hukum seperti al-Quran, hadist, ijmak, dan qiyas (analogi) harus diletakkan dalam konsepsi tersebut.

Di samping itu, konsepsi maqâshid asy-syarîah (Tujuan dasar pemberlakukan hukum Islam) yang berintikan perlindungan pada lima hal pokok (dlarûriyyat alkhamsah) baik pada tingkatan dlarûriyyat, hâjiyyât maupun tahsiniyyât, merupakan prinsip umum yang berintikan pada keadilan dan kebaikan. Dengan demikian inti ajaran Islam yang terdapat dalam universalitas alQuran adalah penegakan prinsip kemanusiaan, dimana perbedaan muslim dan non muslim menjadi tidak terlalu relevan diperdebatkan.

Dalam beberapa literature Fiqh alaqalliyyât selalu membahas mengenai keberadaan masyarakat dalam konteks kewarganegaraan yakni masyarakat muslim di wilayah non muslim. Sejatinya pemahaman mengenai Konsep Fiqh Aqalliyât bisa dikembangkan bukan hanya terkait bagaimana Muslim hidup sebagai minoritas, tapi bagaimana seharusnya Muslim yang berada dalam posisi mayoritas memperlakukan kelompok minoritas serta bagaimana masyarakat minoritas dapat berkontribusi pada masyarakat mayoritas sehingga menimbulkan hubungan yang bersifat simbiosis mutualistik. Perluasan konsep ini dalam konteks ke Indonesiaan, sangat penting terutama untuk memberikan landasan konseptual bahwa melindungi minoritas merupakan bagian dari penegakan nilai-nilai agama.Hal ini sejalan dengan kaidah fiqiyah "hukum bisa berubah disebabkan perubahan waktu dan tempat.

Rumusan tersebut dijadikan sebagai legitimasi bahwa hukum Islam mempunyai fleksibilitas yang tinggi dan senantiasa memperhatikan realitas sebagai dasar pertimbangan untuk menetapkan hukum.

Sebagai lazimnya fiqh klasik, Fiqh alaqalliyyât juga dibangun berdasarkan pondasi kaidah-kaidah hukum (legal maxims) yang dikenal dengan al-qawa'id al fiqhiyyah. Jumlah kaidah-kaidah fikih cukup dan merupakan derivasi dari lima kaidah pokok yang dikenal dengan al-kulliyyat al-khams, yaitu:

1. Semua perkara itu tergantung niatnya

2. Keyakinan tidak bisa dihilangkan oleh keraguan

3. Kesulitan mendatangkan kemudahan

4. Kemadlaratan harus dihilangkan

5. Adat bisa menjadi hukum

Lima kaidah pokok diatas sesungguhnya telah memberikan gambaran awal betapa fikih itu harus mempertimbangkan hal-hal yang paling esensial, yaitu niat dan hal-hal yang memudahkan dan mendatangkan manfaat kemashlahatan. Fiqh al-aqalliyyat bisa disebut juga sebagai fikih nondiskriminasi, karena fikih tersebut didasarkan kepada elaborasi dan formulasi fikih yang berbasis HAM.

Aspek yang penting dalam Fiqh alaqalliyyât diantaranya merujuk kepada aspek mengutamakan nilai-nilai toleran dan keterbukaan untuk berinteraksi dengan masyarakat lain dan konsep wasatiyah serta peluang dakwah kepada kepada masyarakat non muslim. Dalam pandangan fiqih ini tidak hanya mengatur bagaimana sminoritas muslim menjalankan hidup sesuai dengan ajaran syarii, tetapi bagaimana jalan hidup mayoritas muslim untuk memperlakukan orang lain yang berbeda secara adil.

Secara terminolgis Fikih Minoritas berarti satu bentuk fiqh yang memeilihara keterkaitan hukum syar'i dengan dimensidimensi suatu komunitas, dan dengan tempat di 
mana mereka tinggal. Fiqh ini merupakan fiqh komunitas terbatas yang memiliki kondisi khusus, yang memungkinkan sesuatu yang tidak sesuai bagi orang lain menjadi sesuai bagi mereka. Cara memperolehnya membutuhkan aplikasi sebagai ilmu kemasyarakataan secara umum dan ilmu sosiologi, ekonomi dan beberapa ilmu politik dan hubungan internasional secara khusus.

Dari definisi diatas mengindikasikan bahwa Fiqh al-aqalliyyât tetap merupakan salah satu jenis fiqh yang merupakan bagian dari fiqh pada umumnya, hanya saja ia memiliki karakter khusus karena akan diterapkan pada masyarakat dengan karakter khusus, yang berbeda dengan fiqh pada umumnya, yakni masyarakat minoritas disuatu negara.

Dalam konteks kehidupan bernegara, memperlakukan orang lain secara adil, berarti menjadikan HAM dan Konstitusionalisme menjadi basis pengaturan. Seluruh warga negara harus diperlakukan setara, sehingga nilai-nilai agama, etnis, ras, jenis kelamin tidak bisa dijadikan alat untuk mendiskriminasi.Konstruk pemikiran semacam ini tentu mengandung jebakan yang harus dihindari.Konsep "kesetaraan" (equality) justru bisa menjadi alat penindasan bila hal itu diterapkan dalam struktur masyarakat yang sejak awal terkonstruk secara diskriminatif.Karena itu, konsep kesetaraan warga negara harus mengizinkan adanya affirmative action untuk mengangkat kapasitas kelompok yang sejak awal terdiskriminasi atau mempunyai kemampuan yang berbeda dengan mayoritas warga negara pada umumnya.

Perlindungan dan memperlakukan minoritas secara adil dan tidak bertindak diskriminatif, merupakan semangat dari ajaran islam. Dengan begitu, prinsip konstitusionalisme, dan penghargaan warga negara berbasis HAM dengan sendirinya merupakan semangat Islam juga.Sebenarnya dalam implementasinya terdapat beberapa pertentangan antara konsep HAM prespektif Islam dan konsep konstitusionalisme, HAM dan warga negara yang dirumuskan oleh pengalaman masyarakat barat.Problematika hukum ini telah di jawab oleh Ahmed an-Naim, menurutnya penerapan dan elaborasi hukum tersebut dapat direalisasikan, dengan menyediakan ide-ide, asumsi-asumsi dan institusi-institusi yang berkaitan dengan prinsip-prinsip tersebut agar bisa diadaptasi secara lebih baik dalam konteks lokal dan masyarakat yang berbeda.

Suatu kebijakan pemerintah baik yang berupa undang-undang, peraturan hukum dan serta keputusan baik pada tataran nasional maupun internasional harus dapat berkembang sesuai dengan perubahan zaman.Hukum yang bersifat konvensioanal tidak selamanya dapat mengatribusi dan menawarkan solusi bagi problematika dan isu-isu yang bersifat global akibat pengaruh moderinisasi secara luas.Sehingga perubahan hukum dalam konteks keislaman harus berdasarkan koridor nash-nash syariat yang bersifat universal tanpa mengesampingkan nilai-nilai kemanusiaan dan keadilan yang bersifat subtansial bagi masyarakat. Hal ini sesuai dengan kaidah fiqiyah Taghoyurul ahkam bi taghoyuril amkan azman wa ahwal (perubahan hukum harus selaras dengan perubahan tempat, zaman dan keadaan). Perubahan itu haruslah mampu menajawab permasalahan yang ada dan mampu menampung aspirasi serta kondisi sosial masayarakat yang ada semata-mata demi mewujudkan kemashlahatan. Dalam kelompok minoritas terbentuk hukum yang merupakan bawaaan bukan ciptaan yang sering kita kenal dengan livinglaw. Teori living law dari Eegene Ehrinlicch menyatakan bahwa setiap masyarakat terdapat aturan-aturan hukum yang hidup (living law). Semua hukum dianggap hukum sosial.

Dalam memahami sebuah realitas sosial masyarakat, termasuk pada tataran minoritas, Islam selalu membawa pengakuan tersebut dalam kerangka religiusitas.Wilayah keagamaan menjadi sesuatu yang mengatur mengenai pandangan masyarakat terhadap kelompok minoritas selain Islam.Term fikih minoritas (fiqh al-aqalliyyât) sebenarnya tidak dikenal dalam diskursus hukum Islam, terutama hukum Islam klasik.Fikih Islam dengan seluruh pencabangannya dibangun di atas altar kesadaran, Islam adalah mayoritas, pemenang, hidup dalam bangunan negara Islam, dan seterusnya.

Etik Rekognisi Profetik dibutuhkan oleh legislator untuk memperluas dan sekaligus mengasah kepekaan nurani dan spritualnya. Bagi penegak hukum kebutuhannya adalah profetikIntelegence sebagai tawaran pendekatan 
alternatif dalam rangka mengisi rulebanking.Tawaran pendekatan holistik di dunia psikologi yang menyatukan pendekatan cognitive intelegence, emotional intelegence, adversity intelegence, dan spritual intelegence. Integrasi dari setiap etik pendekatan-pendekatan tersebut akan melahirkan rekognisi yang etis. Rekognisi yang etis lahir dari legislator, penegak hukum yang mempunyai integritas.Integritas adalah mutu, sifat, keadaan yang menujukkan kesatuan yang utuh sehingga potensi dan kemampuan memancarkan kewibawaan.

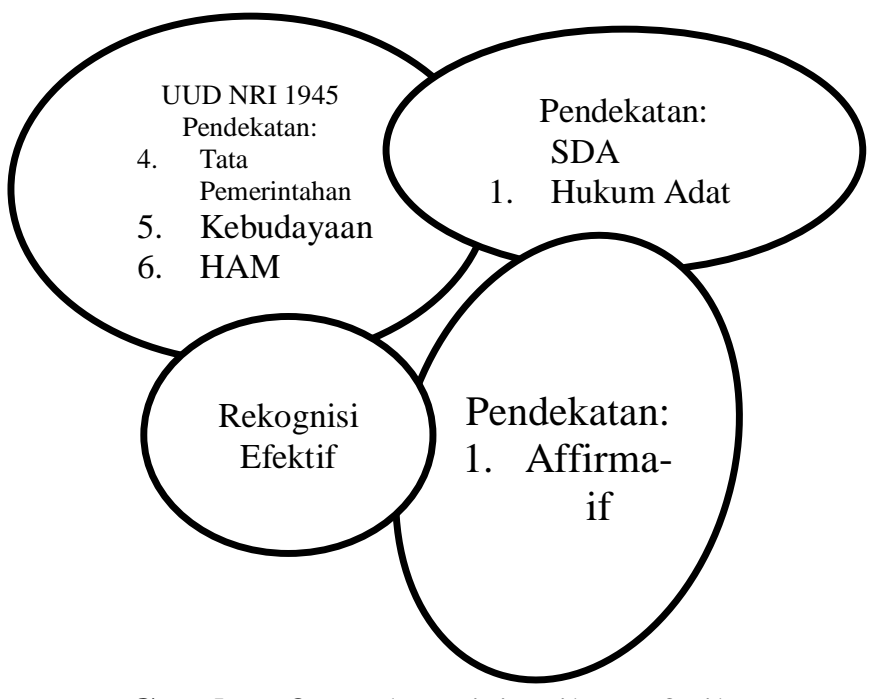

Gambar 3 : Rekognisi Etik Profetik

\section{SIMPULAN DAN SARAN}

Rekognisi idealnya dilakukan dengan pendekatan secara utuh dan affirmatife. Rekognisi dengan pendekatan secara utuh menjamin hak asasi bagi yang direkognisi. Rekognisi affirmative menjamin percepatan rekognisi bagi kelompok atau komunitas yang dulunya pernah ada, lalu direkognisi kembali. Intergrasi antara rekognisi utuh dan affirmative ini disebut sebagai rekognisi etis. Rekognisi etis dan affirmative ini roh dari rekognisi perspektif etik propetik.

Rekognisi hak masyarkat adat diatur dalam UUD NRI 1945 dengan berbagai pendekatan yang dimuat pada masing-masing pasal. Pasal 18B ayat (2) rekognisi dengan pendekatan Tata Pemerintahan, pasal 32 Ayat (1) dan (2) rekoginisi menggunakan pendekatan kebudayaan, pasal 28I rekognisi menggunakan pendekatan hak asasi manusia. Rekognisi dalam konstitusi dengan Pendekatan-Pendekatan tersebut berdampak persoalan hukum pada tataran peraturan dibawahnya bahkan masih menyimpan konflik di wilayah masyarakat adat baik konflik vertikal maupun konflik horizontal. Pendekatan yang dilupakan dalam rekognisi hak masyarakat adat dalam konstitusi adalah pendekatan Sumber daya alam dan pendekatan Hukum adat.

\section{DAFTAR RUJUKAN \\ Buku}

Rian Adhivira Prabowo, Politik Rekognisi Axel Honneth: Relevansinya terhadap Jaminan Kesetaraan dalam Hukum di Indonesia. Jurnal Ilmu Pemerintahan, Vol. 4, No. 2, 2019, 75-88.

Anaya James S,Indigenous Peoples in International Law, (Oxford University Press, 1996), hlm. 13.

Della Porta, Donatella dan Keating, Michael (eds), Approaches and Methodologie in the Social Sciences, Cambridge University Press, 2008. hlm. 171.

Dr. Ahmad Imam Mawardi, MA, Fiqh Minoritas: Fiqh Al- Aqalliyyat dan Evolusi Maqasid al-Syari'ah dari Konsep ke Pendekatan, (Yogyakarta: LkiS Group, 2012), hlm.119.

Muhammad Dahlan, Undang : Jurnal Hukum, Vol. 1 No. 2 (2018), Rekognisi Hak MasyarakatHukum Adat dalam Konstitusi "Fakultas Hukum Universitas Brawijaya. Hal 214

Simarmata, Rikardo 2006 Pengakuan hukum terhadap masyarakat adat di Indonesia. Jakarta: UNDP. Hal. 209)

Yance Arizona, Antara Teks dan konteks: Dinamika pengakuan hukum terhadap hak masyarakat adat atas sumber daya alam di Indonesia .Hal. 19

Kuntowidjoyo, Islam sebagai ilmu.: Efistimologi, metodelogi, dan etika. Yogyakarta. Tiara wacana. 2006. Hal. 9-10

Kelik wardiono dkk, Paradigma Profetik: Eksplorasi awal pengembangan basis epistimologi Ilmu Hukum, Dalam Transendensi Hukum prospek dan implementasi. Genta publishing. Yogyakarta. Hal. 32

Shammai Fishman, "Fiqh al-Aqalliyat: A Legal Theory for Muslim Minorities", 
(Hodson Institute: Research Monograph on the Muslim World, Series No. 1, Paper No. 2, October 2006), dalam Dr. Ahmad Imam Mawardi, Fiqh Minoritas, hlm. 13.

Dr. Subhi Mahmashani, Falsafah al-Tasyri' $f i$ al-Islam, Dar al-'Ilm li al-Malayiin, Beirut, cet. V, hlm.220-223, (http://huseinmuhammad.net/hukumislam-yang-tetap-dan-yangberubah/\#sth ash.p376gTz7.dpuf), akses 26 Novemver 2019

Abdullahi Ahmed an-Naim, Islam dan Negara Sekuler: Menegosiasikan Masa Depan, Syariah, (Bandung: Mizan, 2007), hlm. 210.

Gamal abdul nasir, Mengawal Pengakuan dan eksistensi hak ulayat.taah ulayat masyarakat hukum adat, dalam Hukum Transedental Pengembangan dan Penegakkan Hukum di Indonesia. Genta Publishing., Yogyakarta. hal. 364

Jurnal

Dianto, Kewenangan Kepala Daerah Menerbitkan Izin Usaha Perkebunan Di Hutan Adat, Vol 3, No 2 (2015).

Dianto, Pola Penyelesaian Konflik Rekognisi Hak Masyarakat Adat Di Kabupaten Sumbawa, Jurnal Equilibrium: Jurnal Pendidikan Vol. VIII. Issu 1 